\title{
What Makes a Critic Tick? Connected Authors and the Determinants of Book Reviews
}

\section{Citation}

Dobrescu, Loretti I., Michael Luca, and Alberto Motta. "What Makes a Critic Tick? Connected Authors and the Determinants of Book Reviews." Journal of Economic Behavior \& Organization 96 (December 2013): 85-103.

\section{Published Version}

doi:10.1016/j.jebo.2013.08.008

\section{Permanent link}

http://nrs.harvard.edu/urn-3:HUL.InstRepos:27022530

\section{Terms of Use}

This article was downloaded from Harvard University's DASH repository, and is made available under the terms and conditions applicable to Open Access Policy Articles, as set forth at http:// nrs.harvard.edu/urn-3:HUL.InstRepos:dash.current.terms-of-use\#OAP

\section{Share Your Story}

The Harvard community has made this article openly available.

Please share how this access benefits you. Submit a story.

\section{Accessibility}


H A R VAR D B U S I N E S S S S H O O L

\section{What makes a critic tick? \\ Connected authors and the determinants of book reviews}

Loretti I. Dobrescu

Michael Luca

Alberto Motta

\section{Working Paper}

12-080

August 6, 2013 


\title{
What makes a critic tick? Connected authors and the determinants of book reviews ${ }^{\#}$
}

\author{
Loretti I. Dobrescu ${ }^{\mathrm{a}}, \mathrm{Michael}_{\mathrm{Luca}}^{\mathrm{b}}$, Alberto Motta ${ }^{\mathrm{c}}$
}

2013

\begin{abstract}
This paper investigates the determinants of expert reviews in the book industry. Reviews are determined not only by the quality of the product, but also by the incentives of the media outlet providing the review. For example, a media outlet may have the incentive to provide favorable coverage to certain authors or to slant reviews toward the horizontal preferences of certain readers. Empirically, we find that an author's connection to the media outlet is related to the outcome of the review decision. When a book's author also writes for a media outlet, that outlet is $25 \%$ more likely to review the book relative to other media outlets, and the resulting ratings are roughly 5\% higher. Prima facie, it is unclear whether media outlets are favoring their own authors because these are the authors that their readers prefer or simply because they are trying to collude. We provide a test to distinguish between these two potential mechanisms, and present evidence that this is because of tastes rather than collusion -- the effect of connections is present both for authors who began writing for a media outlet before and after the book release. We then investigate other determinants of expert reviews. Both consumers and expert reviewers seem to favor authors who have won book prizes. Yet relative to consumer reviews, professional critics are less favorable to first time authors and more favorable to authors who have garnered other attention in the press (as measured by number of media mentions outside of the review).
\end{abstract}

\footnotetext{
${ }^{*}$ We would like to thank two anonymous referees for very helpful comments and suggestions. We are also grateful to Dimitris Christelis, Jerry Green, Dara Lee, Dilip Mookherjee, Daniele Paserman, Pian Shu, and Jonathan Smith for useful comments and suggestions. All errors remain our own.

${ }^{\mathrm{a}}$ University of New South Wales, dobrescu@unsw.edu.au

${ }^{\mathrm{b}}$ Harvard Business School, mluca@hbs.edu

${ }^{\mathrm{c}}$ University of New South Wales, motta@unsw.edu.au
} 


\section{Introduction}

Expert reviews published in media outlets pervade our everyday lives. For decisions ranging from choosing a restaurant or a book to planning a vacation or buying a car, media outlets provide much of the information we use. A growing empirical literature has shown that these reviews are influential in a variety of markets (Reinstein and Snyder, 2005; Boatwright, Basuroy, and Kamakura, 2007; Berger, Sorensen, and Rasmussen, 2010). Given this widespread influence, it is critical to understand the content of such reviews; yet little empirical evidence exists. This paper addresses this issue by providing empirical evidence on the determinants of expert reviews in the book industry.

In practice, expert reviews are determined not only by the quality of the product, or even by the tastes of the reviewer, but also by the incentives of the media outlet providing the review. A media outlet may not always have the incentive to provide objective reviews, such as in cases when there is a relationship between the reviewer and the maker of the product. For example, professional critics often write reviews for books of authors to whom they have a connection, such as a colleague at that newspaper.

Connections between a media outlet and an author can undermine the editorial integrity of the process by giving rise to collusion and favorable treatment. Theoretically, collusive incentives may be reduced through careful mechanism design (Laffont and Tirole, 1991; Laffont and Martimort, 1997; Motta, 2012). Even in the absence of collusion, these types of connections can give rise to favorable treatment. An experimental literature has shown that subjects tend to give more in dictator games when they are connected to the recipient (Charness and Gneezy, 2008). Hence, in equilibrium, the impact of connections becomes an empirical question. 
In this paper, we investigate the role of these connections between authors and book reviewers. Specifically, we consider the fact that many non-fiction authors have also served as journalists or opinion writers for newspapers. We present robust evidence that these connections matter. For this analysis, we construct a new data set consisting of the 100 highest rated nonfiction books ${ }^{1}$ on Metacritic.com between 2004 and 2007. To identify a fixed set of recognized expert reviewers, we use the same set of media outlets (magazines and newspapers) that Metacritic uses to identify experts. To identify affiliated authors who are connected with these periodicals, we use a variety of sources (including author biographies in each of these 100 books) to identify which media outlets (if any) each author has worked for.

Our analysis shows that a media outlet is more likely to review a book written by a connected author, and the resulting review is more favorable on average. We begin by regressing a book's likelihood of being reviewed by a given periodical on an indicator for whether the author is connected to that periodical. This may be problematic if connected authors write better books. To control for this, we include book specific fixed effects. Now, the regression is measuring whether an author is more likely to be reviewed by periodicals to which the author is connected. To clarify our identification strategy, consider two authors - one works for the New York Times while the other works for the Wall Street Journal. Our evidence is essentially that the New York Times author tends to receive more favorable reviews from the New York Times, while the Wall Street Journal author tends to receive more favorable reviews from the Wall Street Journal. Overall, we find that being connected to a media outlet increases an author's likelihood of being reviewed by roughly $25 \%$.

Should managers and policymakers be concerned that the connection between an evaluator and the creator of the product is so important? They should be concerned if this is driven by

\footnotetext{
${ }^{1}$ Non-fiction covers science/technology, arts/literature, business, history, sociology, biographies and memoirs, etc.
} 
collusion. Yet there are other reasons why connections might matter. Specifically, different media outlets may have different tastes in books. In our setting, the New York Times has a very different audience than the Village Voice. Further, a book by a New York Times journalist may be preferred by New York Times readers relative to readers of the Village Voice. Hence, even if the authors are reviewed more often by media outlets to which they are connected, it need not be collusion.

We propose a test to distinguish between mechanisms, by exploiting the timing of the connection. Some of the authors wrote the book before writing for a given media outlet, while others wrote the book after becoming connected to a certain media outlet. If the link between being reviewed and writing for a media outlet was due to an effort by the paper to help its authors, then only authors who wrote for the media outlet before the book came out should benefit. However, we find that the likelihood of being reviewed by a given media outlet is statistically indistinguishable between the two groups. While we cannot truly reject that there is collusion, the data suggest that horizontal differentiation plays an important role in the expert review process.

In addition to tastes and bias, there is a third potential interaction between evaluations and connections. Specifically, the New York Times may know more about the work of their authors than about other authors, and therefore have a more precise signal of the quality of their books. For instance, in the NIH grant setting, $\mathrm{Li}$ (2012) finds that evaluators are better able to assess the quality of work of connected applicants. We test for this, but do not find conclusive evidence that this is the case.

The policy implications of these alternative mechanisms are very different. A collusiondriven preferential treatment is tantamount to providing readers with misleading information, 
something that policymakers should be concerned about. Just how concerning collusion is will depend on readers' access to multiple media outlets, and their ability to rationally anticipate collusion and adjust their beliefs accordingly. On the other hand, if the differential treatment reflects horizontal differentiation, with media outlets optimally providing information that caters to the preferences of their respective audiences, then there is no inefficiency. Finally, the third mechanism has yet different policy implications. If critics are better able to assess the quality of work of connected authors, oversampling these authors could be welfare improving from the readers' standpoint. Given how sensitive policy implications are to the presence of alternative mechanisms, it is crucial to determine which ones are active. Ours is an exploratory attempt to disentangle these channels and analyze their relative importance.

Finally, we also consider the relationship between expert and consumer reviews. Both expert and consumer reviews are ultimately written to inform consumers, and hence one might expect the two to be very similar. At the same time, these two types of information are generated in very different ways. Expert reviews are horizontally differentiated (as shown in this paper) and are written by professional critics who may be able to more accurately assess the quality of a book. Using their training and experience, they can assign an instant judgment on a book's quality and place it in context (with respect to the past and current trends) for the readers. On the other hand, there is virtually no quality assurance in consumer reviews. For instance, these reviews can be gamed by the producers or the competitors of a product by submitting fake reviews (Luca and Zervas, 2013; Mayzlin et al., 2012). Further, consumers who choose to leave a review may not reflect the underlying population. Hence, the link between expert and consumer reviews is a priori unclear. 
Empirically, we find that there is no correlation between the likelihood of being reviewed by an expert and a book's Amazon rating. Yet, we find that expert ratings are correlated with Amazon ratings, and so, conditional on leaving a review, experts and consumers agree in aggregate about the quality of a book.

Expert reviews and consumer reviews also systematically diverge at times. Relative to the consumer opinion as measured by Amazon reviews, we find that professional critics are less favorable to first time authors and more favorable to authors who have garnered other attention in the press (as measured by number of media mentions outside of the review). However, both consumers and expert reviewers seem to favor authors who have won book prizes.

Overall, our paper contributes to and connects two different literatures. First, there is a related literature on conflict of interest in the media. Reuter and Zitzewitz (2006) investigate the link between advertisements in media outlets and editorial coverage, and show that some publications provide favorable editorial coverage to advertisers. In work that is concurrent to but independent from ours, DellaVigna and Kennedy (2011) present evidence that media outlets tend to accord more favorable treatment to movies produced by affiliated (connected) studios. They also decompose the possible bias by reviewer and find evidence of reviewer bias, but no evidence of explicit editorial bias (i.e., dismissal of reviewers who are too independent, and assignment of movies to different reviewers). Their work is thus complementary to ours - both show that connections matter. However, their definition of bias is slightly different, something that is largely due to the different type of connections considered. In particular, what we refer to as horizontal differentiation, they simply refer to as bias that is "shared with readers." Despite the differing definitions, our results are largely consistent. Using a smaller and earlier data set, 
Rossman (2003) presents evidence that media outlets are not biased toward movies produced by their parent companies.

Our paper also contributes to the literature on reviews. For example, in a recent paper, Sun (2012) argues that the patterns of consumer reviews on Amazon.com and BarnesAndNoble.com are consistent with a model where variations in reviews are driven by horizontal preferences. Ours is among the first to investigate the determinants of reviews.

\section{Background and Data}

\subsection{The Review Process}

Newspapers and magazines are the primary outlet for expert book reviews. A typical newspaper can review several books per week, or a few hundred per year. With more than 85,000 books published per year in the United States alone, ${ }^{2}$ it is clear that there are many more books than can possibly be reviewed.

The book reviewing process varies between publications, but typically any author can submit his or her book for review. At any given media outlet, a large number of submissions are received each week. The review editors divide these submissions, generally by topic, to prescreen before deciding which to review. At smaller media outlets, journalists can also propose a book to review, which would then be screened by the editors.

A typical process for reviewing can be seen at the New York Times Book Review, where there are several review editors who do the prescreening. For example, one editor screens history books, while another screens books about politics. After the initial screening, the editors reconvene to discuss which books to review. The criteria used for selection are not made public.

\footnotetext{
2 The 2011 Bowker Annual Report on U.S. Print Book Publishing.
} 
Once the selection is made, books are assigned to critics at the discretion of the editors. Critics write the final reviews, which are then published.

In this paper, we do not differentiate between a media outlet (e.g. New York Times) and an individual critic working for the New York Times. Our underlying assumption is that media outlets have some degree of discretion in choosing their critics, ${ }^{3}$ as well as the books that will be reviewed.

\subsection{Review Data}

Our sample consists of all reviews written by a fixed set of media outlets for each of the 100 highest rated non-fiction books on Metacritic during the years 2004-2007. We choose the years 2004-2007 because these are the years in which Metacritic regularly reviewed books, and hence for which we have scores assigned to each review. We use Metacritic.com (described below) to collect reviews for each book, and a variety of sources to identify which media outlets (if any) each author has worked for.

There are many expert reviews for any given book, and the definition of expert is a fuzzy one. Since we are interested in understanding the role of bias in expert reviews, we want to restrict the list of reviewers to recognized experts. To do this, we use Metacritic's list of media outlets to restrict the sample to 40 media outlets.

We rely on Metacritic because it is a well-known aggregator of expert reviews. Its function is to collect reviews from a set of media outlets and summarize them in a way that can be easily compared by consumers. To facilitate this, Metacritic normalizes reviews given by different

\footnotetext{
${ }^{3}$ After a book is chosen to be reviewed, the selection of a reviewer begins. Generally, in the pre-screening process several possible reviewers are proposed for each book recommended for review. The editor then decides which reviewer will be asked to review what book, depending on the willingness to take the book on its own terms, narrative skill, a track record (i.e., established authors have the right to be assessed by equally established reviewers), and professionalism in working with editors and deadlines (Calame, 2005).
} 
media outlets to the same scale. If a score has not been assigned by the media outlet, Metacritic develops a score based on the content of the review.

In Metacritic, each book review is mapped to a grade of Terrible, Mixed, Mostly Favorable, Good, or Outstanding. We use all the reviews left for the 100 highest rated books on Metacritic in any of the 40 media outlets recognized by Metacritic. Our two main dependent variables are an indicator for whether book $i$ was reviewed by media outlet $j$ and the quality grade (rating) assigned to book $i$ by media outlet $j$ for the books that are reviewed.

Finally, we augment the expert reviews with consumer reviews from Amazon. Anyone can leave a review on Amazon by registering an email address to create an account. Reviews consist of a 1 to 5 star rating, as well as text. The mean ratings for the books in this sample range from 3.1 to 5 stars. All books in this sample have received reviews on Amazon. A more general overview of the issues surrounding the consumer review process can be found in Luca (2010).

\subsection{Description of Books}

We focus on a sample of elite books: the top 100 rated non-fiction books in Metacritic. We combine the Amazon and Metacritic data with other characteristics of the book and author, including whether this was the author's first book, the frequency with which the author is mentioned in the New York Times (outside of the review), whether the book is a major book prize winner, and whether the author is connected to each of the media outlets that reviewed his or her book.

Table 1 presents summary statistics. On average, these media outlets review 39\% of the books in the sample, giving a rating of 3.2 out of 4 . To highlight the popularity of these books, consider the fact that more than 85,000 books are published each year in the United States alone, 
while each of these media outlets reviews less than $0.5 \%$ of them. By contrast, the same media outlets review roughly $50 \%$ of these books chosen for review. Hence, there is at least some agreement about which books are best.

Roughly $15 \%$ of authors in our sample have won a major book prize, and $17 \%$ are first-time authors. The authors tend to receive considerable media coverage, even outside of the book review section. On average, an author is mentioned 208 times by the New York Times outside of the book review section. This number is skewed, ranging from 2 mentions to 3,975 mentions. These books also tend to do well among consumer reviews, receiving a mean Amazon rating of 4.25 stars out of 5 .

We choose this sample for three main reasons. First, our focus is on connections between media outlets and book authors. The authors of non-fiction books are very often journalists, but this is rarely the case for authors of fiction books. Also, non-fiction is where the reviews may matter more, as the expertise of the critics can offer additional information on placing a book in previous and current contexts. Second, the books we use correspond to Metacritic's most extensive list of elite books. Additionally, Metracritic's review aggregator ensures consistency in the way expert reviews are quantified and aggregated. Finally, there is no reason why our key estimates should be biased if our sample is drawn from the top 100 books. Although the elite books are the most reviewed, there is no a priori expectation on why connections should or should not matter for this sample. On the one hand, since these are top books, one could arguably expect the returns to favoritism for this sample to be low. ${ }^{4}$ On the other hand, elite book reviews could be where gift exchange between authors and reviewers takes place, but not further down the quality distribution.

\footnotetext{
${ }^{4}$ The average book in the sample gets 14 reviews. One might expect that the decision to give a book a 15 th review is largely about tastes, and a desire to help the author might matter more in the decision to give a book a first or second review.
} 


\section{Theoretical Framework}

\section{Books}

A book is characterized by vertical quality $q$ and a set of attributes $A=\left\{a_{1}, \ldots, a_{\mathrm{n}}\right\}$. These attributes capture a variety of features including whether a book is well-written, funny, or socially relevant.

\section{Media Outlets}

Media outlet $j$ has preferences over attributes $A$, represented by weights $\Lambda_{\mathrm{j}}=\left\{\alpha_{1 \mathrm{j}}, \ldots\right.$, $\left.\alpha_{\mathrm{nj}}\right\}$, with $\Sigma_{\mathrm{k}=1}{ }^{\mathrm{n}} \alpha_{\mathrm{k}}=1$. The set $\Lambda_{\mathrm{j}}$ can be thought of as reviewer tastes, or as the reviewer's preference to cater to a certain audience. Essentially, this allows some reviewers to prefer biographies, while others prefer Civil War history. With full information about the book, the media outlet has preferences $u_{\mathrm{j}}=q+\alpha_{1 \mathrm{j}} a_{1}+\alpha_{2 \mathrm{j}} a_{2}+\ldots+\alpha_{\mathrm{nj}} a_{\mathrm{n}}$.

\section{$\underline{\text { Reviews and Asymmetric Information }}$}

Characteristics $q$ and $A$ are unobservable, and it is common knowledge that $u_{\mathrm{j}}$ has a normal

distribution with mean $u_{\mathrm{j}}{ }^{\mathrm{a}}$ and precision $\eta, u_{\mathrm{j}} \sim N\left(u_{\mathrm{j}}{ }^{\mathrm{o}}, \eta^{-1}\right)$. Each media outlet receives a noisy signal of $u_{\mathrm{j}}$ given by $z=u_{\mathrm{j}}+v$, where $v$ is i.i.d. with a known distribution, also normal, $v \sim N(0$, $\left.\delta^{-1}\right)$. Upon observing signal $z$, the media outlet updates the expected preferences to

$$
\mathrm{E}\left[u_{\mathrm{j}} \mid z\right]=\left(\eta u_{\mathrm{j}}^{\mathrm{o}}+\delta z\right) /(\eta+\delta)
$$

A media outlet that is reporting its preferences will then report $\theta=\left(\eta u_{\mathrm{j}}^{\mathrm{o}}+\delta z\right) /(\eta+\delta)$.

\section{Testable Hypotheses}

The focus of this paper is to understand whether and, if so, why authors with a connection to a media outlet receive favorable treatment. In this section, we use this framework to elucidate three competing hypotheses and the corresponding empirical tests that we will be running. 


\section{Hypothesis 1: Connections and Correlated Preferences}

Suppose that some authors are connected to the media outlet, and others are not. Allow these authors to be of different types - connected $c$ and unconnected $n$. Then, reporting the media outlet's preferences would yield average reports $\mathrm{E}\left[\theta_{\mathrm{c}}\right]$ and $\mathrm{E}\left[\theta_{\mathrm{n}}\right]$. Empirically if, from the perspective of any given media outlet, these authors are of different types, then it should be the case that $\mathrm{E}\left[\theta_{\mathrm{c}}\right] \neq \mathrm{E}\left[\theta_{\mathrm{n}}\right]$. This would happen if there is a correlation between the authors that a media outlet chooses to hire and the media outlet's preferences over books. We would then see that connections matter even before the connection began.

\section{Hypothesis 2: Connections and Collusion}

Media outlets may try to give favorable treatment to connected authors. We can think of favorable treatment as collusion, wherein both the connected author and the media outlet stand to gain from an inflated review. Authors clearly gain sales from a favorable review. For example, Berger et al. (2010) show a causal effect of not only a positive New York Times review, but even of a negative one, on book sales. But the success of an author may also benefit the media outlet by improving its reputation. We denote this extra gain by $b$. Hence, in the presence of collusion, the media outlet has preferences

$$
u_{\mathrm{j}}^{\mathrm{c}}=\mathrm{E}\left[q+\alpha_{1 \mathrm{j}} a_{1}+\alpha_{2 \mathrm{j}} a_{2}+\ldots+\alpha_{\mathrm{nj}} a_{\mathrm{n}} \mid z\right]+b .
$$

We can also interpret $b$ as arising from other types of favoritism, rather than explicit collusion. For example, experimental evidence suggests that people act more favorably toward those with a higher degree of social kinship (Charness and Gneezy, 2008). In this case, $b$ could arise from a reviewer who favors a book due to the author's social proximity.

Empirically, if $b$ arises from the connection to the media outlet, then $b$ would only be present for authors who were connected at the time the review was written. There would be no 
favoritism for books written by authors who would become connected at some point in the future.

\section{Hypothesis 3: Connections and Precision of Information}

While collusion is one potential negative consequence associated with connections, there are potential positive benefits as well. Li (2012) argues that an evaluator may be biased toward people to whom they are connected, but may also have more information about these people, creating a tension between information and objectivity. Li applies this idea to NIH grants, and shows that grant evaluators provide favorable treatment to grant applicants whom they have cited, but also have more information about.

Similarly, media outlets may know more about connected authors. In our setting, this informational advantage could be represented by having more precise signals about the book when the author is connected. This may be a consequence of their close relationship with the author of the book, which makes it easier for them to assess the value of the book. Or it could be due to the alleviation of the moral hazard problem that might arise if the expert reviewer needs to exert effort to acquire information.

Media outlets would then have two types of noise, $v_{\mathrm{c}} \sim N\left(0, \delta_{\mathrm{c}}{ }^{-1}\right)$ and $v_{n} \sim N\left(0, \delta_{\mathrm{n}}{ }^{-1}\right)$, where $\delta_{c}>\delta_{n}$. This would yield reports $\theta_{\mathrm{c}}=\left(\eta u_{\mathrm{o}}+\delta_{c} z\right) /\left(\eta+\delta_{c}\right)$ and $\theta_{\mathrm{n}}=\left(\eta u_{\mathrm{o}}+\delta_{n} z\right) /\left(\eta+\delta_{n}\right)$. Reports given for connected authors would then be more strongly correlated with $u_{\mathrm{j}}$.

\section{Determinants of Reviews}

We investigate the determinants of expert reviews in two different ways. First, we investigate the variation of reviews across different media outlets. Second, we investigate the differences between expert and consumer reviews. 
The estimating equation is

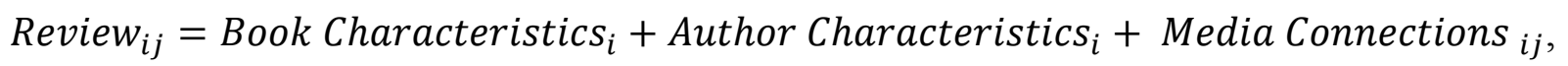

for all reviews of book $i$ at media outlet $j$.

All specifications include media outlet fixed effects and some specifications also include book fixed effects. We use logit models to estimate the likelihood of being reviewed and OLS models for the book's rating, and we cluster standard errors at the book level.

As a robustness check, we run several alternative specifications. First, we cluster standard errors by media outlet and obtain very similar results. Second, since the score obtained by a book is a count variable, all specifications involving book ratings were re-run using both Poisson and negative binomial models. Similarly, all of the specifications involving the likelihood of being reviewed were re-run using linear probability models. We find that all our main results hold. Third, when studying the likelihood of being reviewed, we also experiment with a variable denoting the number of Amazon reviews, rather than the Amazon score. Once more, we find that our main results remain unchanged. Fourth, a concern one might have is whether our results hold if we cluster standard errors both by book and media outlet. Since the book and media outlet dimensions cannot be nested, we employ a two-way clustering method to address this issue (Cameron, Gelback and Miller, 2011). Using this method, all logit, OLS, and Poisson models are re-run and yield very similar results to our benchmark models, only slightly less significant in some cases.

One final concern is that the estimated impact of connections on ratings is subject to selection bias. As we will show below, connections affect the likelihood of being reviewed, which is likely related to the ratings. In section 4.1.1, we discuss and model the potential 
direction of any bias. Empirically, the impact of connections on ratings is robust to selection corrections using several different excluded variables.

\section{1 The Role of Connections}

Many non-fiction authors work as journalists (either as opinion writers or in the news sections of media outlets). In this section, we present evidence that these authors are more likely to be reviewed by the media outlet for which they write relative to other media outlets, and that the resulting review tends to be more favorable.

Empirically, we can simply regress a book's rating at a media outlet on the author's affiliation (indicating whether the author is affiliated with that media outlet), controlling for book and media outlet specific unobservable characteristics. Table 2 investigates the impact of connections. Depending on the specification, a media outlet is roughly $25 \%$ more likely to review a book written by someone affiliated with it.

The identification of this effect is being driven by the inclusion of controls for other media outlets at which the book was reviewed, and ultimately a book fixed effect. If we were to simply regress the likelihood of being reviewed on whether an author is a journalist, there could be concerns about omitted variable bias because the econometrician does not observe the quality of the book. By including a book fixed effect, the coefficient on the affiliated author variable is telling us the likelihood that a book is being reviewed at the author's connected media outlet relative to other media outlets. We are essentially differencing out the book's likelihood of being reviewed across all media outlets, since the likelihood of being reviewed is likely correlated with the book's unobserved quality. 
We include a media outlet fixed effect because the likelihood of being reviewed at different media outlets varies for reasons that are uncorrelated with the quality of the book, such as space constraints at different media outlets.

The results in Table 3 provide further insight into the determinants of expert reviews. A book's overall rating is roughly 0.2 stars higher when the author of the book has been affiliated with that particular media outlet. This is also robust to the inclusion of book and media outlet specific fixed effects. ${ }^{5}$

Finally, we also investigate whether these effects hold for all types of media outlets, i.e., mainstream U.S. newspapers (New York Times, Wall Street Journal, etc.), magazines (New Yorker, Entertainment Weekly, The Nation, etc.), and all other sources. ${ }^{6}$ The results, which are available from the authors upon request, show that the role of connections in the decision to review is largest in mainstream U.S. newspapers. While there are differences in the impact of connections on ratings, these differences are not statistically significant.

This result can be compared with a small existing literature on the determinants of media information. In terms of political behavior of newspapers, Puglisi and Snyder (2011) document the New York Times Democratic partisanship. In finance, Reuter and Zitzewitz (2006) show that major personal finance magazines (Money, Kiplinger's Personal Finance, and SmartMoney) are more likely to recommend funds that have previously advertised within their pages. Our results can also be compared to Fowder, Kadiyali, and Prince (2011), who also consider bias in reviews. They find $6 \%$ lower ratings for movies that have a black lead actor. Lastly, our results can relate to Michaely and Womack (1999), who find that brokerage analysts usually recommend stocks

\footnotetext{
${ }^{5}$ To the extent that the likelihood of receiving a review increases for connected authors, the rating may also change due to selection. However, this goes in the opposite direction of our result, since we see that ratings increase for connected authors.

${ }^{6}$ For a complete list of media outlets, see Appendix 1.
} 
from companies recently taken public by their firms. Moreover, these stocks generally perform worse than the ones recommended by non-connected brokers.

\subsubsection{Robustness to Selection Bias}

Our results show that an author is more likely to be reviewed by media outlets with which he or she has connections. Moreover, an author's rating is higher, on average, at connected media outlets. These results are large and robust to the inclusion of book fixed effects, meaning that the findings are being identified by variation within a book across media outlets (driven by cases where authors are connected to at least one, but not all media outlets).

While it is clear that the first finding implies favorable treatment of connected authors, one might be concerned that the second finding is being driven by selection bias - even with a book fixed effect. In particular, the second finding shows that - on average - a book receives higher ratings from connected media outlets. However, there is a clear a missing data problem - we only observe ratings in cases where the media outlet has left a review. Since being connected increases the likelihood of being reviewed, it is necessary to think about the marginal books written by connected authors that are now being reviewed but otherwise would not be (in the absence of a connection). Specifically, our interpretation (that connected authors receive favorable treatment in terms of ratings) would be challenged if the marginal books were of higher quality than the books that were already being reviewed. However, a priori, it seems reasonable to assume that media outlets review the books of the highest quality first. Then, once all the best books have been reviewed, they proceed reviewing those of lower quality. This assumption is consistent with our empirical findings - there is a strong positive correlation between the probability of a book being published and the average rating. In this case, the 
marginal books, which are reviewed because of the author's connection, are likely to be of lower quality and their ratings will be lower accordingly. Hence, our estimated impact of connections on a book's rating would simply be downward biased and could be viewed as a lower bound of the true estimate, while our qualitative interpretation would remain unchanged.

However, we do not want to rely on this assumption. Hence, in this section, we formally address the possibility of selection bias without explicitly assuming the direction of bias. The preponderance of evidence suggests that the effect of connections on ratings is not being driven by selection. In addition to formalizing our intuition about the potential direction of selection bias, we show that our results are robust to selection corrections using several different excluded variables.

\subsubsection{Should we expect selection bias?}

This section formalizes the brief discussion in the previous section, highlighting that the potential direction of selection bias depends on the relationship between a media outlet's decision to review a book and the quality of the book. Suppose that a media outlet is able to review a fixed number of books: $N=N_{c}+N_{n}$, where $N_{c}$ and $N_{n}$ denote the number of books by connected and non-connected authors. Further suppose that within each category there is a continuum of books. By assumption, the sum of vertical $(q)$ and horizontal $\left(\alpha_{1 j} a_{1}+\alpha_{2 j} a_{2}+\ldots+\right.$ $\left.\alpha_{\mathrm{nj}} a_{\mathrm{n}}\right)$ qualities $Q_{c}$ and $Q_{n}$ are a strictly decreasing function of the number of books: $Q_{c}=F_{c}\left(N_{c}\right)$ and $Q_{n}=F_{n}\left(N_{n}\right)$, where $F_{c}^{\prime}($.$) and F_{n}^{\prime}($.$) are everywhere strictly negative over the support [0, N]$.

The outlet then selects $N_{c}$ and $N_{n}$ to maximize the overall quality of the books reviewed. For the sake of exposition, we focus here on interior solutions. Any interior solution $\left(N_{c}^{*}, N_{n}^{*}\right)$ must 
satisfy $F_{c}^{\prime}\left(N_{c}^{*}\right)=F_{n}^{\prime}\left(N_{n}^{*}\right)$. This formalizes the notion that media outlets are more likely to review books that they like.

Now suppose that a media outlet deviates from this and replaces a measure of nonconnected books with a measure of connected books. In this situation, the marginal increase in books by connected authors would lead to a decrease in the average of observed ratings of connected authors $\mathrm{E}\left(Q_{c}\right)$, an increase in the average of observed ratings of non-connected authors $\mathrm{E}\left(Q_{n}\right)$, and a decrease in the estimated impact of connections on ratings subject to selection bias. Hence, our connection estimates would be a lower bound. Of course, this relies on the underlying assumption of the shape of $F_{c}($.$) and F_{n}($.$) . In the next section, we empirically$ address this potential selection issue so as not to have to rely on this assumption.

\subsubsection{Testing for Selection}

In this section, we test for selection bias using three different exclusion restrictions denoting: i) whether the book's genre is a popular one (i.e., history or biography, as supposed to science/technology, sociology, business, memoir or arts/literature), ${ }^{7}$ ii) whether a book has been launched in the busiest period of the year to publish (i.e., January, September, October, 1st half of November for all genres, and 2nd half of November for biographies), ${ }^{8}$ and iii) the number of other books published by an author in the same year. Here is the rationale for using these instruments. While publishing a book in a popular category or in one of the best months might affect the likelihood of it being reviewed, this should not have an effect on ratings. Similarly, the fact that an author has published other books in the same year, might affect the probability of getting a review, but not the book's rating.

\footnotetext{
${ }^{7}$ Smailes (2011).

${ }^{8}$ Krames (2009), Willsie (2011).
} 
The starting point to test for selection bias is the parametric model estimated via the fullinformation maximum likelihood (FIML) procedure (Heckman, 1974). Results are presented in Table 2a in the Appendix. Specifications (1), (3) and (5) provide the coefficients of the selection equation (i.e., likelihood of being reviewed), while specifications (2), (4) and (6) show the coefficients of the outcome equation (i.e., rating). For identification, we allow the selection equation to contain (at least) one variable (i.e., the exclusion restriction) that is not included in the outcome equation. In all specifications, the corresponding Wald test of independence between the selection and the outcome equations decisively prevents us from rejecting the null of no correlation between the unobserved determinants of propensity to review and ratings. We can therefore conclude that the two equations are independent and that our OLS estimates of the rating specifications using the subsample of reviewed books (Table 3) are consistent.

The FIML rests on the assumption of bivariate normality of the errors in the two equations. A more robust estimation procedure, known as Heckman's two-step estimator (Heckman, 1979), does not require the normality of the second stage equation. We also implement this not-fully parametric model (which uses the inverse Mills ratio as a regressor) and present the results in Table $2 \mathrm{~b}$ in Appendix. We note that the coefficient of the inverse Mills ratio is clearly not significant in all specifications, which further suggests that selection bias is not driving our results. If we then compare these coefficient estimates with the ones of the OLS model (Table 3), we see that they are indeed very similar. Moreover, the variable denoting connections continue to be significant in both the specifications where the exclusion restrictions matter.

Finally, for both the FIML and the Heckman two-step model, we have also experimented with simultaneously including two (out of the three available) exclusion variables, as well as considering all three exclusion variables together, and results remained unchanged. 


\subsubsection{The Value of Connections}

To put the role of connections into context, we perform a back of the envelope calculation to quantify the value of a review. In order to do this, we need an estimate of the impact of reviews on sales to pair with the impact of connections on reviews. While we do not have data to estimate the impact of reviews on sales, we can use estimates from other papers.

Sorensen and Rasmussen (2004) for instance estimate the impact of being reviewed in the New York Times on book sales. They find that being reviewed leads to roughly a $35 \%$ increase in sales (even if the review is unfavorable), while a positive review leads to an additional $28 \%$ increase in sales.

Our results show that connected authors are 25 percentage points more likely to be reviewed, which therefore translates to roughly a $9 \%$ increase in sales. This estimate accounts for the increased likelihood of review, but not the quality of review. A quick glance at Figure 1, however, reveals that this rating effect is not insignificant. Our results indeed also show that an author who is connected is roughly $10 \%$ more likely to have a review of "outstanding" or "very good", conditional on being reviewed. The value of this is the probability of being reviewed times the expected gain from a better review (conditional on being reviewed). Since a connected author has roughly a $75 \%$ chance of being reviewed by a connected media outlet, the value of the better review is roughly $2 \%$.

Overall, this suggests that being connected to the New York Times increases a book's sales by approximately $11 \%$. Since the New York Times has a larger readership than other media outlets, the value of connections is likely smaller for other media outlets.

\section{2 Tests for Collusion}


There are two potential drivers behind the favorable treatment of connected authors. First, it could be that media outlets are trying to collude with their own authors by providing reviews that are higher than the actual quality. Second, it could be horizontal differentiation, where the authors that write for a media outlet are particularly appealing to the readers of that outlet.

In this section, we provide a test to identify whether the effect is being driven by collusion or horizontal differentiation. In particular, we exploit the fact that some authors wrote the book before writing for a given media outlet, while other became connected only after their book was reviewed by that outlet. If collusion were driving the result, then only authors who were already working for the media outlet would receive favorable treatment from that media outlet. On the other hand, if the results were driven by horizontal differentiation, then authors who will later write for a media outlet would already be appealing to that media outlet based on their writing style. Hence, under horizontal differentiation, we should find no significant difference between the authors based on when the connection started. Table 4 presents the results. When testing the hypothesis that the coefficients on "Also Connected Before" and "Connected Only After" are the same, the t-tests yield p-values above $10 \%$ in all specifications. ${ }^{9}$ Hence, the evidence clearly supports the horizontal differentiation and not the collusion hypothesis. Empirically, the reviews given to authors who have already written for a given media outlet are no more favorable than those given to authors who will later write for that media outlet. ${ }^{10}$ Among the three media types, however, the positive association between likelihood of being reviewed and connections, either current or future, appears significant only for mainstream U.S. journals, which is in line with our previous findings.

\footnotetext{
${ }^{9}$ To get an idea on how powerful this test is, we note that in our sample, a third of the connected authors started their connection with a media outlet only after being reviewed by that media outlet.

${ }^{10}$ The coefficients of the two connection variables in Table 4 are not statistically significant in some specifications. However, given their large standard errors, we may not be able to rule out an economically significant effect of these variables on the likelihood of being reviewed.
} 
As a final remark, please note that if a book has limited commercial success, media outlets might consider hiring the author at low cost in exchange for a good review. A good review might help boosting sales, which is particularly beneficial if a book lacks consumers' traction. But a media outlet might also decide to hire a book's author precisely because the book is a commercial success. This could occur if the media outlet caters to the general consumers' tastes (and not only to its own audience), perhaps in the attempt to gain market shares or increase its general prestige. It could also indicate that the media outlet is unable to determine whether to hire an author without a signal from consumers. As a falsification test, we regress the quality rating of Amazon reviews on whether the author has become connected with a media outlet only after being reviewed by it. The estimates in Table 5 show that there is no association between an author's different connection timing and consumer reviews, which rules out these types of hypothesis.

\section{3 Test for Connections and Precision of Information}

The previous sections have demonstrated that media outlets are more likely to review books by connected authors and books of higher quality (as measured by the book's fixed effect). One would also like to test whether the elasticity of likelihood of review with respect to book quality is different for connected authors, and in particular for connected authors who wrote for a media outlet before being reviewed by it. Media outlets may have more information about book quality (and hence be more responsive to it) for these authors, who they know better. Table 6 presents the results. Specifications 1 through 3 demonstrate that review elasticity with respect to book quality (i.e. fixed effect) is larger for authors who have written for a given media outlet. If this is an information effect deriving from formal connections, then we should see this effect to be 
larger after the author becomes connected. However, we lack power to test this (as evidenced by the large standard errors in the last column). ${ }^{11}$

\section{4 Other Determinants of Expert Reviews}

The previous section establishes that horizontal differentiation is an important part of the expert review process. At the same time, expert reviews should ultimately reflect some measure of product quality as well. Consumer reviews, on the other hand, are more complicated as they represent "popular appeal", not "professional judgment" (Holbrook, 1999). The quality rating from consumer reviews may be called into question because of the selection of reviews, since we do not know who is leaving the review. Further, professional reviewers may have a different sense of what it means to be a "quality" book.

To test this, we compare expert reviews to consumer reviews from Amazon.com. On average, we find that consumers and experts have correlated preferences. Indeed, the estimates in Table 3 show a strong positive association between the quality of consumer reviews and the quality of expert reviews. On the other hand, Table 2 shows that there is no correlation between the likelihood of being reviewed by experts and consumer ratings. This is not surprising, especially given that our sample consists of non-fiction books. Particularly in this case, media outlets may have an advantage over the consumers because their reviewers generally have superior knowledge in that area or have access to privileged information and can claim expertise. Hence, the set of books reviewed by the experts can be easily very different from what consumers would choose.

\footnotetext{
${ }^{11}$ We also experimented with a variable denoting the average rating of each book (instead of the book fixed effect) and found that our results did not change substantially.
} 
There are also other ways in which consumer and expert opinion differ. Relative to consumer reviews, experts reward books written by authors who have received media attention (measured by the number of mentions of the authors in the New York Times outside of the book review section). On the other hand, consumer reviews tend to favor books by first time authors. But both consumers and expert reviewers tend to prefer books that won major book awards.

To further investigate the differences between expert and consumer reviews, we run a Seemingly Unrelated Regression of the two outcome variables (likelihood of being reviewed and rating) on several common forcing variables: whether the book won any prizes, whether this is the author's first book, and the number of times the author was mentioned in New York Times. The method takes advantage of the possible correlation in unobservables between the two regressions and allows one to establish the correlation between experts and consumer reviews by testing the difference between the corresponding coefficients, even though the dependent variables are scaled differently. Results are presented in Table 7. The Breusch-Pagan test shows that the two regression residuals are not independent. In this specification, the coefficients of "Book Prize Winner" are not significantly different for experts vs. consumers. On the other hand, the effects for first time authors and authors with media mentions in the New York Times are statistically distinct. However, we cannot exclude that these results are driven by experts catering to the tastes of their readers (i.e., readers of media outlets that employs them) and not to Amazon consumers.

Overall, this suggests that while consumer reviews and expert reviews are correlated, there are systematic differences. ${ }^{12}$ Consumer reviews may help to reach books by newer, less established authors, whereas experts may be more favorable to established, popular authors.

\footnotetext{
${ }^{12}$ Holbrook (1999) reached a similar result for the movie industry (i.e., ordinary consumers and professional critics reviews, although correlated, show different standards of evaluation).
} 
This close overall correlation between experts and consumers suggests that experts are at least reflecting consumer opinion, as measured by reviews, rather than simply announcing their own beliefs (at least in cases where the beliefs are widely divergent).

\section{Discussion}

In this paper we look at the determinants of expert reviews in the book industry. We find that an author's connection to the media outlet is related to the outcome of the review decision. When a book author also writes for a media outlet, that outlet is $25 \%$ more likely to review the book relative to other media outlets, and the resulting ratings are roughly $5 \%$ higher. We investigate a number of alternative mechanisms that could explain this bias. Media outlets might favor their own authors because these are the authors that their readers prefer or simply because they have better information about them. Alternative, they might be trying to collude. We provide a test to distinguish between these potential mechanisms, and present evidence that this is because of tastes rather than collusion. On the other hand, we do not find conclusive evidence that the bias is due to the precision or quality of information.

Our results have important policy implications. Policymakers should be concerned if the bias is due to collusion, because that would entail exposing readers to misleading information. On the other hand, if the bias were due to horizontal differentiation, or the precision of information, no intervention would be required. Given that each mechanism has a specific impact on social welfare, it is crucial to determine which one is indeed operating. Ours is an exploratory attempt to disentangle these channels and analyze their relative importance.

This paper also investigates the relation between consumer and expert reviews. The estimates show that the latter do indeed reflect consumer tastes as measured by Amazon reviews. 
Relative to consumer reviews, however, experts tend to favor more established authors, whereas consumers tend to favor first-time authors. Both types of reviews however appear more favorable to book prize winners.

Finally, there are several limitations of this paper. First, while we are able to provide clear estimates of the overall impact of connections, we are unable to fully empirically distinguish between mechanisms. Given the different policy implications of each mechanism, an important direction for future research is to continue to investigate the mechanisms behind this type of connection effect. Second, the effects considered in this paper are all at the media outlet level. Hence, we do not investigate the existence of reviewers-specific patterns in the rating of books. If a pattern exists, it is important to study what factors can explain the distinct responses by different reviewers. Analyzing the heterogeneity in reviewers' responses within and across media outlets might shed light on important aspects not yet analyzed by the media economics literature. The media ownership structure might also influence reviewers' behavior and ultimately affect readers. We leave these extensions to future research. 


\section{References}

Berger, J., Sorenson, A., Rasmussen, S. (2010) Positive Effects of Negative Publicity: When Negative Reviews Increase Sales. Marketing Science 29:5, 815-827.

Boatwright, P., Basuroy, S., Kamakura, W. (2007) Reviewing the Reviewers: The Impact of Individual Film Critics on Box Office Performance. Quantitative Market Economics 5, 401-425.

Calame, B. (2005) The Book Review: Who Critiques Whom and Why? http://www.nytimes.com /2005/12/18/opinion/18publiceditor.html?pagewanted=all

Cameron, C., Gelbach, J., Miller, D. (2011) Robust Inference with Multiway Clustering. Journal of Business and Economic Statistics 29:2, 238-249.

Charness, G., Gneezy, U. (2008) What's in a Name? Anonymity and Social Distance in Dictator and Ultimatum Games. Journal of Economic Behavior \& Organization 68, 29-35.

DellaVigna, S., Kennedy, A. (2011) Does Media Concentration Lead to Biased Coverage? Evidence from Movie Reviews, working paper.

Fowder, L., Kadiyali, V., Prince, J. (2011) Racial Bias in Quality Assessment: A Study of Newspaper Movie Reviews. Johnson School Research Paper Series No. 7-2010.

Heckman, J. (1974) Shadow prices, market wages, and labor supply. Econometrica 42, 679-694.

Heckman, J. (1979) Sample Selection Bias as a Specification Error. Econometrica 47, 153-161.

Holbrook, M.B. (1999) Popular Appeal Versus Expert Judgments of Motion Pictures. Journal of Consumer Research 26, 144-155.

Krames, J. (2009) When Is the Best Time to Publish a Business Book? http://jeffreykrames.com /2009/09/23/when-is-the-best-time-to-publish-a-business-book/

Laffont, J.J., Martimort D. (1997) Collusion under asymmetric information. Econometrica 65, 875-911.

Laffont, J.J., Tirole, J. (1991) The Politics of Government Decision-Making: A Theory of Regulatory Capture. Quarterly Journal of Economics 106:4, 1089-1127.

Li, D. (2012) Information, Bias, and Efficiency in Expert Evaluation: Evidence from the NIH, working paper.

Luca, M. (2010) Reviews, Reputation, and Revenue: The Case of Yelp.com, working paper.

Luca, M., Zervas, G. (2013) Fake It Till You Make It: Reputation, Competition, and Yelp Review Fraud, working paper.

Mayzlin, D., Dover, Y, Chevalier, J. (2012) Promotional Reviews: An Empirical Investigation of Online Review Manipulation, working paper. 
Michaely, R., Womack, K.L. (1999) Conflict of Interest and the Credibility of Underwriter Analyst Recommendations. Review of Financial Studies 12:4, 653-686.

Motta, A. (2012) Collusion and Selective Supervision Available at SSRN: http://papers.ssrn.com/sol3/papers.cfm?abstract_id=1922412.

Puglisi, R., Snyder, J.M. (2011) Newspaper Coverage of Political Scandals. Journal of Politics, forthcoming.

Reinstein, D., Snyder, C. (2005) The Influence of Expert Reviews on Consumer Demand for Experience Goods: A Case Study of Movie Critics. Journal of Industrial Economics 53, 27-52.

Reuter, J., Zitzewitz, E. (2006) Do Ads Influence Editors? Advertising and Bias in the Financial Media. Quarterly Journal of Economics 121:1, 197-227.

Rossman, G. (2011) The Influence of Ownership on the Valence of Media Content: The Case of Movie Reviews, working paper.

Smailes, G. (2011) What Is The Best Book Genre To Write? http://bubblecow.net/what-is-thebest-genre-to-write-if-you-want-to-get-published/

Sorensen, A.T., Rasmussen, S.J. (2004) Is Any Publicity Good Publicity? A Note on the Impact of Book Reviews, working paper.

Sun, M. (2012) How Does the Variance of Product Ratings Matter? Management Science 58:4, 696-707.

Willsie, C. (2011) What's the Best Time of Year to Publish?

http://www.greenleafbookgroup.com/blog/2011/10/12/whats-the-best-time-of-year-to-publish 


\section{Tables and Figures}

Table 1: Summary Statistics

\begin{tabular}{lrrrr}
\hline & Mean & SD & Min & Max \\
\hline \hline Review & 0.39 & 0.52 & 0 & 1 \\
Connected Author & 0.025 & 0.16 & 0 & 1 \\
Connection Began Before the Book Review & 0.016 & 0.12 & 0 & 1 \\
Expert Ratings (scale of 1-4) & 3.21 & 0.74 & 1 & 4 \\
Number of Reviews Per Media Outlet & 34.90 & 25.08 & 1 & 93 \\
First Time Author & 0.17 & 0.38 & 0 & 1 \\
Book Prize Winner & 0.15 & 0.36 & 0 & 1 \\
\# of Mentions in New York Times & 208.54 & 504.68 & 2 & 3975 \\
Amazon Rating (scale of 1-5) & 4.25 & 0.36 & 3.1 & 5 \\
\hline \hline
\end{tabular}

Notes: The data is based on the 100 highest non-fiction rated books on Metacritic, and the 40 media outlets whose reviews are considered into this rating. In our sample, $54 \%$ of the books have a journalist author and $41 \%$ have the author connected to a media outlet prior to the review. 
Table 2: Determinants of Expert Review Frequency

\begin{tabular}{|c|c|c|c|c|c|c|c|c|c|}
\hline \multicolumn{10}{|c|}{ Likelihood of being reviewed } \\
\hline & (1) & (2) & (3) & (4) & (5) & (6) & (7) & (8) & (9) \\
\hline Connected Author & $\begin{array}{c}0.267 * * * \\
(0.052)\end{array}$ & $\begin{array}{c}0.273 * * * \\
(0.052)\end{array}$ & $\begin{array}{c}0.270 * * * \\
(0.052)\end{array}$ & $\begin{array}{c}0.275^{* * *} * \\
(0.052)\end{array}$ & $\begin{array}{c}0.275 * * * \\
(0.052)\end{array}$ & $\begin{array}{c}0.281 * * * \\
(0.051)\end{array}$ & $\begin{array}{c}0.261 * * * \\
(0.050)\end{array}$ & $\begin{array}{c}0.246^{* * *} \\
(0.054)\end{array}$ & $\begin{array}{c}0.225 * * * \\
(0.053)\end{array}$ \\
\hline First Time Author & & $\begin{array}{c}-0.059^{*} \\
(0.036)\end{array}$ & $\begin{array}{l}-0.061^{*} \\
(0.036)\end{array}$ & $\begin{array}{c}-0.070 * * \\
(0.030)\end{array}$ & $\begin{array}{c}-0.070^{* *} \\
(0.031)\end{array}$ & $\begin{array}{c}-0.066^{* *} \\
(0.029)\end{array}$ & $\begin{array}{c}-0.067 * * \\
(0.029)\end{array}$ & & \\
\hline Book Prize Winner & & & $\begin{array}{c}0.045 \\
(0.032)\end{array}$ & $\begin{array}{c}0.048 \\
(0.030)\end{array}$ & $\begin{array}{c}0.047 \\
(0.031)\end{array}$ & $\begin{array}{l}0.054^{*} \\
(0.031)\end{array}$ & $\begin{array}{l}0.054^{*} \\
(0.031)\end{array}$ & & \\
\hline \# of Mentions in New York & & & & & & & & & \\
\hline Times & & & & $\begin{array}{c}0.005^{* *} \\
(0.003)\end{array}$ & $\begin{array}{c}0.005^{* * *} \\
(0.002)\end{array}$ & $\begin{array}{c}0.006 * * * \\
(0.002)\end{array}$ & $\begin{array}{c}0.007 * * * \\
(0.002)\end{array}$ & & \\
\hline Amazon Score & & & & & $\begin{array}{c}0.003 \\
(0.034)\end{array}$ & $\begin{array}{c}0.016 \\
(0.035)\end{array}$ & $\begin{array}{c}0.015 \\
(0.036)\end{array}$ & & \\
\hline U.S. Topic & & & & & & $\begin{array}{c}-0.052^{*} \\
(0.028)\end{array}$ & $\begin{array}{c}0.009 \\
(0.029)\end{array}$ & & \\
\hline U.S. Topic X non-U.S. Media & & & & & & & - & & - \\
\hline Outlet & & & & & & & $\begin{array}{c}0.277 * * * \\
(0.059)\end{array}$ & & $\begin{array}{c}0.292 * * * \\
(0.062)\end{array}$ \\
\hline Media Outlet FE & $\mathrm{x}$ & $\mathrm{x}$ & $\mathrm{x}$ & $\mathrm{x}$ & $\mathrm{x}$ & $\mathrm{x}$ & $\mathrm{x}$ & $\mathrm{x}$ & $\mathrm{x}$ \\
\hline Book FE & & & & & & & & $\mathrm{x}$ & $\mathrm{x}$ \\
\hline Obs & 3756 & 3756 & 3756 & 3756 & 3756 & 3756 & 3756 & 3721 & 3721 \\
\hline
\end{tabular}

Notes: Specifications (1) - (9) are logit models (marginal effects reported). The dependent variable indicates whether a book has been reviewed in a media outlet. Connected Author indicates whether an author has written for a media outlet. Book Prize Winner indicates whether the book has won any of the following awards: National Book Award, Whitbread Book of the Year, Pulitzer Prize, American Booksellers Association Award, Publishers Weekly Book of the Year, Arthur Ross Book Award, American Book Award, Lincoln Prize, Anisfield-Wolf Book Awards, Theatre Book, New South Wales Premier's Literary Awards, George Washington Book Prize, and National Book Critics Circle Award. U.S. Topic includes biographies of American politicians, authors, and business people, as well as memoirs by Americans and history of American events.

Standard errors (robust and clustered by book) are in parentheses below estimated parameters.

$* * *$ p-value $<0.01, * *$ p-value $<0.05, *$ p-value $<0.1$. 


\begin{tabular}{|c|c|c|c|c|c|c|c|c|c|}
\hline & & & & & ating & & & & \\
\hline & (1) & (2) & (3) & (4) & $(5)$ & (6) & $(7)$ & (8) & (9) \\
\hline Connected Author & $0.180 *$ & $0.184^{*}$ & $0.187^{*}$ & $0.199 *$ & $0.199 * *$ & $0.200 * *$ & $0.200 * *$ & $0.219 * *$ & $0.218 * *$ \\
\hline & $(0.105)$ & $(0.106)$ & $(0.105)$ & $(0.104)$ & $(0.104)$ & $(0.103)$ & $(0.104)$ & $(0.099)$ & $(0.099)$ \\
\hline First Time Author & & -0.051 & -0.060 & -0.083 & $-0.109 * *$ & $-0.109 * *$ & $-0.109 * *$ & & \\
\hline & & $(0.068)$ & $(0.069)$ & $(0.051)$ & $(0.051)$ & $(0.051)$ & $(0.051)$ & & \\
\hline Book Prize Winner & & & $0.166^{* * *}$ & $0.171 * * *$ & $0.140 * * *$ & $0.142 * * *$ & $0.142 * * *$ & & \\
\hline & & & $(0.053)$ & $(0.053)$ & $(0.049)$ & $(0.049)$ & $(0.049)$ & & \\
\hline \# of Mentions in New & & & & & & & & & \\
\hline York Times & & & & $0.008 *$ & $0.009 * *$ & $0.009 * *$ & $0.009 * *$ & & \\
\hline & & & & $(0.004)$ & $(0.004)$ & $(0.004)$ & $(0.004)$ & & \\
\hline Amazon Score & & & & & $0.166 * * *$ & $0.168 * * *$ & $0.168 * * *$ & & \\
\hline & & & & & $(0.060)$ & $(0.058)$ & $(0.058)$ & & \\
\hline U.S. Topic & & & & & & -0.011 & -0.012 & & \\
\hline & & & & & & $(0.046)$ & $(0.046)$ & & \\
\hline U.S. Topic X non-U.S. & & & & & & & & & \\
\hline Media Outlet & & & & & & & 0.004 & & -0.022 \\
\hline & & & & & & & $(0.129)$ & & $(0.132)$ \\
\hline Media Outlet FE & $\mathrm{x}$ & $\mathrm{x}$ & $\mathrm{x}$ & $\mathrm{x}$ & $\mathrm{x}$ & $\mathrm{X}$ & $\mathrm{X}$ & $\mathrm{X}$ & $\mathrm{x}$ \\
\hline Book FE & & & & & & & & $\mathrm{x}$ & $\mathrm{X}$ \\
\hline Obs & 1414 & 1414 & 1414 & 1414 & 1414 & 1414 & 1414 & 1414 & 1414 \\
\hline
\end{tabular}

Notes: Specifications (1) - (9) are OLS models. The dependent variable indicates the rating assigned to a book by a media outlet. Connected Author indicates whether an author has written for a media outlet. Book Prize Winner indicates whether the book has won any of the following awards: National Book Award, Whitbread Book of the Year, Pulitzer Prize, American Booksellers Association Award, Publishers Weekly Book of the Year, Arthur Ross Book Award, American Book Award, Lincoln Prize, Anisfield-Wolf Book Awards, Theatre Book, New South Wales Premier's Literary Awards, George Washington Book Prize, and National Book Critics Circle Award. U.S. Topic includes biographies of American politicians, authors, and business people, as well as memoirs by Americans and history of American events.

Standard errors (robust and clustered by book) are in parentheses below estimated parameters.

$* * *$ p-value $<0.01, * *$ p-value $<0.05, *$ p-value $<0.1$. 


\begin{tabular}{|c|c|c|c|c|c|c|c|c|}
\hline & \multicolumn{4}{|c|}{ Likelihood of being reviewed } & \multicolumn{4}{|c|}{ Rating } \\
\hline & $\begin{array}{l}\text { Mainstream } \\
\text { US Journals } \\
\end{array}$ & Magazines & $\begin{array}{c}\text { Alternative } \\
\text { Sources } \\
\end{array}$ & $\begin{array}{c}\text { Whole } \\
\text { Sample }\end{array}$ & $\begin{array}{l}\text { Mainstream } \\
\text { US Journals } \\
\end{array}$ & Magazines & $\begin{array}{c}\text { Alternative } \\
\text { Sources } \\
\end{array}$ & $\begin{array}{l}\text { Whole } \\
\text { Sample }\end{array}$ \\
\hline & (1) & (2) & (3) & (4) & (5) & (6) & (7) & (8) \\
\hline $\begin{array}{l}\text { Connected Only } \\
\text { After }\end{array}$ & $\begin{array}{l}0.599 * * \\
(0.282)\end{array}$ & $\begin{array}{l}-0.041 \\
(0.242)\end{array}$ & $\begin{array}{l}-0.023 \\
(0.152)\end{array}$ & $\begin{array}{l}0.225 * * \\
(0.112)\end{array}$ & $\begin{array}{c}0.199 \\
(0.165)\end{array}$ & $\begin{array}{l}0.754 * * * \\
(0.165)\end{array}$ & $\begin{array}{l}0.676^{*} \\
(0.368)\end{array}$ & $\begin{array}{c}0.338 * * \\
(0.148)\end{array}$ \\
\hline Also Connected Before & $\begin{array}{l}0.663 * * * \\
(0.254)\end{array}$ & $\begin{array}{l}0.105 \\
(0.097)\end{array}$ & $\begin{array}{r}0.248 * \\
(0.129)\end{array}$ & $\begin{array}{l}0.242 * * * \\
(0.066)\end{array}$ & $\begin{array}{l}-0.171 \\
(0.181)\end{array}$ & $\begin{array}{c}0.316 \\
(0.218)\end{array}$ & $\begin{array}{c}0.289 \\
(0.210)\end{array}$ & $\begin{array}{c}0.118 \\
(0.143)\end{array}$ \\
\hline First Time Author & $\begin{array}{l}-0.081 \\
(0.062)\end{array}$ & $\begin{array}{c}-0.093 * * * \\
(0.032)\end{array}$ & $\begin{array}{c}0.018 \\
(0.034)\end{array}$ & $\begin{array}{c}-0.059 * * \\
(0.028)\end{array}$ & $\begin{array}{l}-0.014 \\
(0.104)\end{array}$ & $\begin{array}{l}-0.108 \\
(0.092)\end{array}$ & $\begin{array}{l}-0.090 \\
(0.072)\end{array}$ & $\begin{array}{c}-0.075 * * \\
(0.057)\end{array}$ \\
\hline Book Prize Winner & $\begin{array}{l}0.121 * * \\
(0.064)\end{array}$ & $\begin{array}{c}0.026 \\
(0.036)\end{array}$ & $\begin{array}{c}0.028 \\
(0.040)\end{array}$ & $\begin{array}{l}0.053 * \\
(0.031)\end{array}$ & $\begin{array}{c}0.132 \\
(0.108)\end{array}$ & $\begin{array}{c}0.109 \\
(0.079)\end{array}$ & $\begin{array}{c}0.146 * * \\
(0.073)\end{array}$ & $\begin{array}{l}0.135 * * * \\
(0.049)\end{array}$ \\
\hline $\begin{array}{l}\# \text { of Mentions in } \\
\text { New York Times }\end{array}$ & $\begin{array}{c}0.006 \\
(0.003)\end{array}$ & $\begin{array}{l}0.006 * * * \\
(0.002)\end{array}$ & $\begin{array}{c}0.006 * * \\
(0.003)\end{array}$ & $\begin{array}{c}0.006^{* * *} \\
(0.002)\end{array}$ & $\begin{array}{l}0.008 * \\
(0.004)\end{array}$ & $\begin{array}{c}0.003 \\
(0.003)\end{array}$ & $\begin{array}{l}0.014 * \\
(0.005)\end{array}$ & $\begin{array}{l}0.009 * * \\
(0.004)\end{array}$ \\
\hline Amazon Score & $\begin{array}{c}0.057 \\
(0.058)\end{array}$ & $\begin{array}{l}0.083 * * \\
(0.037)\end{array}$ & $\begin{array}{l}-0.057 \\
(0.057)\end{array}$ & $\begin{array}{c}0.019 \\
(0.035)\end{array}$ & $\begin{array}{l}0.277 * * * \\
(0.104)\end{array}$ & $\begin{array}{l}-0.035 \\
(0.084)\end{array}$ & $\begin{array}{l}0.226^{* * *} \\
(0.082)\end{array}$ & $\begin{array}{l}0.179 * * * \\
(0.059)\end{array}$ \\
\hline U.S. Topic & $\begin{array}{c}0.030 \\
(0.044)\end{array}$ & $\begin{array}{l}-0.039 \\
(0.033)\end{array}$ & $\begin{array}{c}0.038 \\
(0.038)\end{array}$ & $\begin{array}{c}0.007 \\
(0.028)\end{array}$ & $\begin{array}{c}0.048 \\
(0.077)\end{array}$ & $\begin{array}{l}-0.108 \\
(0.069)\end{array}$ & $\begin{array}{l}-0.003 \\
(0.079)\end{array}$ & $\begin{array}{l}-0.026 \\
(0.047)\end{array}$ \\
\hline $\begin{array}{l}\text { U.S. Topic X non-U.S. } \\
\text { Media Outlet }\end{array}$ & & $\begin{array}{c}-0.290 * * * \\
(0.090)\end{array}$ & $\begin{array}{l}-0.264 * * * \\
(0.061)\end{array}$ & $\begin{array}{c}-0.276 * * * \\
(0.058)\end{array}$ & & $\begin{array}{l}0.121 \\
(0.290)\end{array}$ & $\begin{array}{l}-0.029 \\
(0.154)\end{array}$ & $\begin{array}{c}0.001 \\
(0.128)\end{array}$ \\
\hline Media Outlet FE & $\mathrm{x}$ & $\mathrm{x}$ & $\mathrm{x}$ & $\mathrm{x}$ & $\mathrm{x}$ & $\mathrm{x}$ & $\mathrm{x}$ & $\mathrm{x}$ \\
\hline Obs & 986 & 1272 & 1554 & 3812 & 480 & 419 & 538 & 1437 \\
\hline
\end{tabular}

Notes: Specifications (1) - (4) are logit (marginal effects reported), while specifications (5) - (8) are OLS models. The dependent variable indicates whether a book has been reviewed in a media outlet (specifications 1-4) and the rating obtained (specifications 5-8). Connected Only After indicates whether an author has written for a media outlet only after being reviewed by that media outlet. Also Connected Before indicates whether an author has written for a media outlet before being reviewed by that media outlet. Book Prize Winner indicates whether the book has won any of the following awards: National Book Award, Whitbread Book of the Year, Pulitzer Prize, American Booksellers Association Award, Publishers Weekly Book of the Year, Arthur Ross Book Award, American Book Award, Lincoln Prize, Anisfield-Wolf Book Awards, Theatre Book, New South Wales Premier's Literary Awards, George Washington Book Prize, and National Book Critics Circle Award. U.S. Topic includes biographies of American politicians, authors, and business people, as well as memoirs by Americans and history of American events.

Standard errors (robust and clustered by book) are in parentheses below estimated parameters. $* * *$ p-value $<0.01, * * p$-value $<0.05$, * p-value $<0.1$. 


\begin{tabular}{|c|c|c|c|c|c|c|c|}
\hline & & & & Ama & ating & & \\
\hline & (1) & (2) & (3) & (4) & (5) & (6) & (7) \\
\hline Connected Author & 0.017 & 0.037 & 0.022 & 0.014 & 0.012 & 0.000 & 0.000 \\
\hline & $(0.044)$ & $(0.048)$ & $(0.049)$ & $(0.047)$ & $(0.047)$ & $(0.048)$ & $(0.048)$ \\
\hline Connected Only After & & -0.082 & -0.104 & -0.102 & -0.107 & -0.115 & -0.115 \\
\hline & & $(0.064)$ & $(0.071)$ & $(0.068)$ & $(0.068)$ & $(0.070)$ & $(0.070)$ \\
\hline First Time Author & & & $0.176 * *$ & $0.167^{*}$ & $0.172 * *$ & $0.158 *$ & $0.158 *$ \\
\hline & & & $(0.084)$ & $(0.086)$ & $(0.087)$ & $(0.087)$ & $(0.087)$ \\
\hline Book Prize Winner & & & & $0.195 * *$ & $0.193 * *$ & $0.173 *$ & $0.173^{*}$ \\
\hline & & & & $(0.094)$ & $(0.094)$ & $(0.091)$ & $(0.092)$ \\
\hline \# of Mentions in New York Times & & & & & -0.004 & $-0.006 *$ & $-0.006^{*}$ \\
\hline & & & & & $(0.003)$ & $(0.003)$ & $(0.003)$ \\
\hline U.S. Topic & & & & & & $0.123 *$ & $0.123 *$ \\
\hline & & & & & & $(0.070)$ & $(0.070)$ \\
\hline U.S. Topic X non-U.S. Media Outlet & & & & & & & -0.003 \\
\hline & & & & & & & $(0.005)$ \\
\hline Media Outlet FE & $\mathrm{x}$ & & $\mathrm{x}$ & $\mathrm{x}$ & $\mathrm{x}$ & $\mathrm{x}$ & $\mathrm{x}$ \\
\hline Obs & 3758 & 3758 & 3758 & 3758 & 3758 & 3758 & 3758 \\
\hline
\end{tabular}

Notes: Specifications (1) - (7) are OLS models. The dependent variable indicates the rating assigned to a book by Amazon. Connected Author indicates whether an author has written for a media outlet. Connected Only After indicates whether an author has written for a media outlet only after being reviewed by that media outlet. Book Prize Winner indicates whether the book has won any of the following awards: National Book Award, Whitbread Book of the Year, Pulitzer Prize, American Booksellers Association Award, Publishers Weekly Book of the Year, Arthur Ross Book Award, American Book Award, Lincoln Prize, Anisfield-Wolf Book Awards, Theatre Book, New South Wales Premier's Literary Awards, George Washington Book Prize, and National Book Critics Circle Award. U.S. Topic includes biographies of American politicians, authors, and business people, as well as memoirs by Americans and history of American events.

Standard errors (robust and clustered by book) are in parentheses below estimated parameters.

$* * *$ p-value $<0.01, * *$ p-value $<0.05, *$ p-value $<0.1$. 
Table 6: Book Quality and the Expert Review Frequency

\begin{tabular}{|c|c|c|c|c|c|}
\hline & \multicolumn{5}{|c|}{ Likelihood of being reviewed } \\
\hline & (1) & (2) & (3) & (4) & (5) \\
\hline Also Connected Before & $\begin{array}{l}-0.027 \\
(0.115)\end{array}$ & $\begin{array}{l}-0.212 \\
(0.160)\end{array}$ & $\begin{array}{c}0.062 \\
(0.137)\end{array}$ & $\begin{array}{l}-0.037 \\
(0.125)\end{array}$ & $\begin{array}{c}-0.106 \\
(1404)\end{array}$ \\
\hline Connected Author & $\begin{array}{c}0.285^{* * *} \\
(0.092)\end{array}$ & $\begin{array}{c}0.285^{* * *} \\
(0.095)\end{array}$ & & $\begin{array}{l}0.134 \\
0.124\end{array}$ & $\begin{array}{l}0.178 \\
(1.397)\end{array}$ \\
\hline Book FE & $\begin{array}{l}-0.0001 \\
(0.0003)\end{array}$ & $\begin{array}{l}-0.0001 \\
(0.0003)\end{array}$ & $\begin{array}{l}-0.0001 \\
(0.0003)\end{array}$ & $\begin{array}{l}-0.0001 \\
(0.0003)\end{array}$ & $\begin{array}{l}-0.0001 \\
(0.0003)\end{array}$ \\
\hline $\begin{array}{l}\text { Also Connected Before X } \\
\text { Book FE }\end{array}$ & & $\begin{array}{l}0.004 * \\
(0.002)\end{array}$ & $\begin{array}{l}0.004 * \\
(0.002)\end{array}$ & & $\begin{array}{c}0.001 \\
(0.173)\end{array}$ \\
\hline $\begin{array}{l}\text { Connected Author X Book } \\
\text { FE }\end{array}$ & & & & $\begin{array}{l}0.003^{*} \\
(0.002)\end{array}$ & $\begin{array}{c}0.002 \\
(0.174)\end{array}$ \\
\hline Media Outlet FE & $\mathrm{x}$ & $\mathrm{x}$ & $\mathrm{x}$ & $\mathrm{x}$ & $\mathrm{x}$ \\
\hline Obs & 3756 & 3756 & 3756 & 3756 & 3756 \\
\hline
\end{tabular}

Notes: Specifications (1) - (5) are logit models (marginal effects reported). The dependent variable indicates whether a book has been reviewed in a media outlet. Also Connected Before indicates whether an author has written for a media outlet before being reviewed by that media outlet. Connected Author indicates whether an author has written for a media outlet. Book FE capture the book fixed effects from specification (8) in Table 3.

Bootstrapped standard errors are in parentheses below estimated parameters.

$* * *$ p-value $<0.01, * *$ p-value $<0.05, *$ p-value $<0.1$.

Table 7: Expert vs. Consumer Ratings

\begin{tabular}{lcc}
\hline & Expert Rating (1-4) & Amazon Rating (1-5) \\
\hline \hline & $(1)$ & $(2)$ \\
First Time Author & -0.035 & $0.167^{* * *}$ \\
& $(0.054)$ & $(0.025)$ \\
Book Prize Winner & $0.144^{* * *}$ & $0.188^{* * *}$ \\
& $(0.053)$ & $(0.024)$ \\
$\#$ of Mentions in New York Times & $0.00006^{*}$ & $-0.00005^{* * *}$ \\
& $(0.00003)$ & $(0.00001)$ \\
\hline Obs & & 100 \\
\hline \hline
\end{tabular}

Notes: Specifications (1) - (2) are SUR (Seemingly Unrelated Regression) models. The dependent variable indicates the rating assigned to a book by a media outlet (Rating) or by consumers (Amazon). Book Prize Winner indicates whether the book has won any of the following awards: National Book Award, Whitbread Book of the Year, Pulitzer Prize, American Booksellers Association Award, Publishers Weekly Book of the Year, Arthur Ross Book Award, American Book Award, Lincoln Prize, Anisfield-Wolf Book Awards, Theatre Book, New South Wales Premier's Literary Awards, George Washington Book Prize, and National Book Critics Circle Award. U.S.

Robust standard errors are in parentheses below estimated parameters.

$* * *$ p-value $<0.01, * *$ p-value $<0.05, *$ p-value $<0.1$. 
Figure 1

\section{Distribution of Reviews by Author Affiliation}

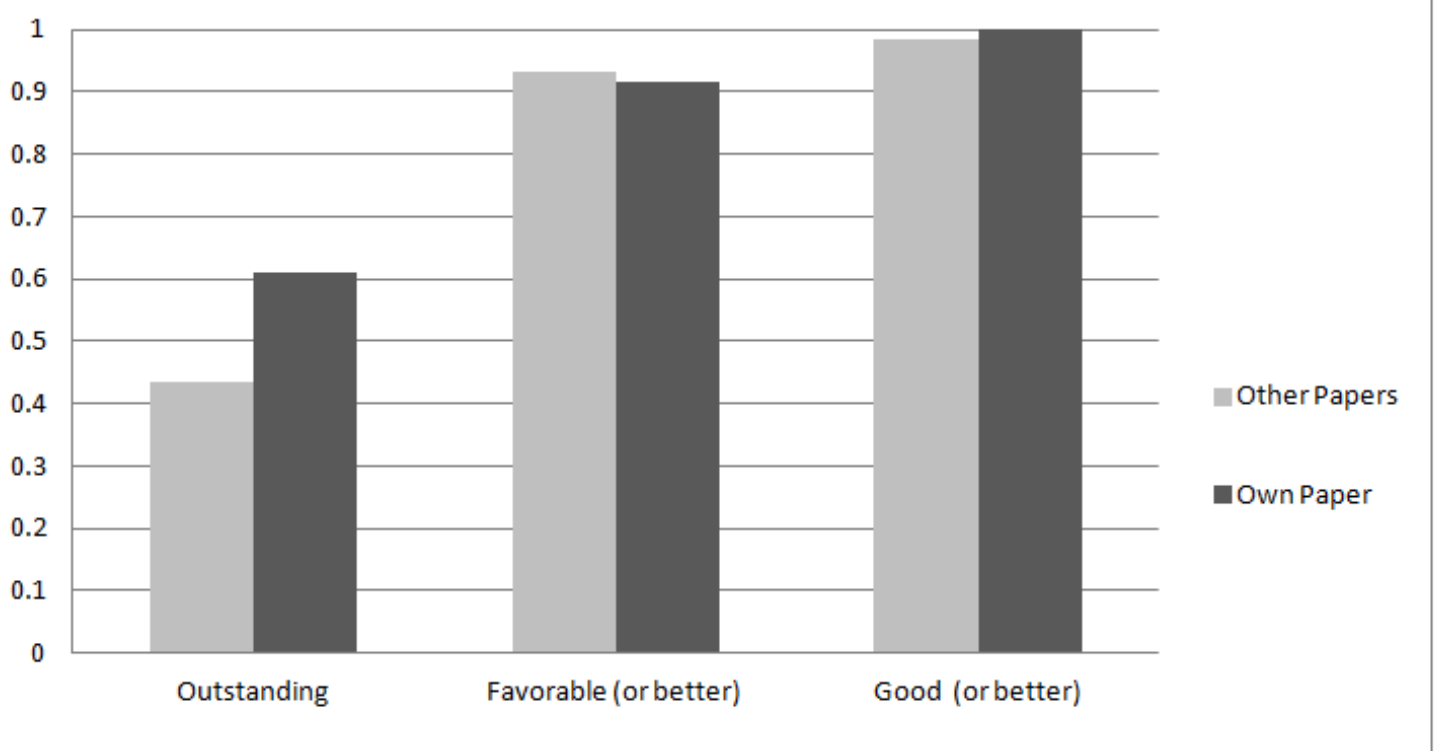


Appendix 1: Summary of Book Reviewers

\begin{tabular}{|c|c|c|c|c|}
\hline Type & Periodical & Percent Reviewed & Mean & SD \\
\hline Alternative & Village Voice & $15 \%$ & 3.4 & 0.51 \\
\hline Alternative & The Onion A.V. Club & $17 \%$ & 3.3 & 0.60 \\
\hline Book Review Magazine & London Review Of Books & $15 \%$ & 2.6 & 0.90 \\
\hline Book Review Magazine & New York Review Of Books & $29 \%$ & 3.2 & 0.78 \\
\hline Book Review Magazine & Booklist & $72 \%$ & 3.4 & 0.55 \\
\hline Book Review Magazine & New York Times Book Reviews & $72 \%$ & 2.9 & 0.84 \\
\hline Book Review Magazine & The Times Literary Supplement & $7 \%$ & 2.8 & 0.38 \\
\hline Book Review Magazine & Kirkus Reviews & $82 \%$ & 3.4 & 0.68 \\
\hline Magazine & The Nation & $15 \%$ & 2.7 & 0.80 \\
\hline Magazine & The Spectator & $39 \%$ & 3.0 & 0.93 \\
\hline Magazine & Atlantic Weekly & $6 \%$ & 2.8 & 0.75 \\
\hline Magazine & The New Yorker & $32 \%$ & 3.0 & 0.50 \\
\hline Magazine & The Economist & $37 \%$ & 3.1 & 0.84 \\
\hline Magazine & LA Weekly & $7 \%$ & 3.1 & 0.69 \\
\hline Magazine & PopMatters & $7 \%$ & 3.4 & 0.53 \\
\hline Magazine & The New Republic & $15 \%$ & 3.2 & 0.67 \\
\hline Magazine & Entertainment Weekly & $50 \%$ & 3.0 & 0.79 \\
\hline Magazine & New York Observer & $21 \%$ & 3.2 & 0.62 \\
\hline Magazine & Library Journal & $64 \%$ & 3.3 & 0.60 \\
\hline Magazine & Christian Science Monitor & $33 \%$ & 3.4 & 0.62 \\
\hline Magazine & Publishers Weekly & $93 \%$ & 3.6 & 0.59 \\
\hline Mainstream International & The Globe And Mail [Toronto] & $35 \%$ & 3.2 & 0.76 \\
\hline Mainstream International & Sydney Morning Herald & $7 \%$ & 3.3 & 0.75 \\
\hline Mainstream International & The Independent & $42 \%$ & 3.0 & 0.85 \\
\hline Mainstream International & Daily Telegraph & $66 \%$ & 3.1 & 0.67 \\
\hline Mainstream International & The Observer & $12 \%$ & 3.3 & 0.53 \\
\hline Mainstream International & The Guardian & $50 \%$ & 3.3 & 0.66 \\
\hline Mainstream US & The New York Times & $60 \%$ & 3.0 & 0.76 \\
\hline Mainstream US & Washington Post & $86 \%$ & 3.0 & 0.81 \\
\hline Mainstream US & Wall Street Journal & $37 \%$ & 3.1 & 0.76 \\
\hline Mainstream US & Chicago Sun-Times & $24 \%$ & 3.3 & 0.91 \\
\hline Mainstream US & Los Angeles Times & $69 \%$ & 3.1 & 0.77 \\
\hline Mainstream US & USA Today & $11 \%$ & 3.3 & 0.50 \\
\hline Mainstream US & Boston Globe & $65 \%$ & 3.1 & 0.76 \\
\hline Mainstream US & Chicago Tribune & $45 \%$ & 3.2 & 0.66 \\
\hline Mainstream US & San Francisco Chronicle & $58 \%$ & 3.3 & 0.57 \\
\hline Mainstream US & Houston Chronicle & $33 \%$ & 3.3 & 0.54 \\
\hline Website & Bookslut & $2 \%$ & 2.0 & 1.41 \\
\hline Website & Slate & $9 \%$ & 2.8 & 0.83 \\
\hline Website & Salon & $21 \%$ & 3.0 & 0.97 \\
\hline
\end{tabular}




\begin{tabular}{|c|c|c|c|c|c|c|}
\hline & $\begin{array}{c}\text { Likelihood of } \\
\text { being } \\
\text { reviewed } \\
\end{array}$ & Rating & $\begin{array}{l}\text { Likelihood of } \\
\text { being reviewed }\end{array}$ & Rating & $\begin{array}{l}\text { Likelihood of } \\
\text { being reviewed }\end{array}$ & Rating \\
\hline & (1) & (2) & (3) & (4) & (5) & (6) \\
\hline \multirow[t]{2}{*}{ Connected Author } & $0.713 * *$ & $0.213 * *$ & $0.707 * * *$ & $0.207^{*}$ & $0.702 * * *$ & $0.229 * *$ \\
\hline & $(0.136)$ & $(0.108)$ & $(0.137)$ & $(0.117)$ & $(0.136)$ & $(0.104)$ \\
\hline \multirow[t]{2}{*}{ First Time Author } & $-0.191 * *$ & $-0.112 * *$ & $-0.173 * *$ & $-0.110 *$ & $-0.201 * * *$ & $-0.116^{* *}$ \\
\hline & $(0.076)$ & $(0.052)$ & $(0.076)$ & $(0.054)$ & $(0.075)$ & $(0.052)$ \\
\hline \multirow[t]{2}{*}{ Book Prize Winner } & 0.139 & $0.144 * * *$ & $0.138^{*}$ & $0.143 * * *$ & $0.134^{*}$ & $0.148 * * *$ \\
\hline & $(0.090)$ & $(0.049)$ & $(0.084)$ & $(0.049)$ & $(0.083)$ & $(0.049)$ \\
\hline \multirow[t]{2}{*}{ \# of Mentions in New York Times } & $0.021 * * *$ & $0.009 * *$ & $0.016^{* * *}$ & $0.009^{*}$ & $0.016^{* * *}$ & $0.010 * *$ \\
\hline & $(0.005)$ & $(0.004)$ & $(0.006)$ & $(0.005)$ & $(0.006)$ & $(0.005)$ \\
\hline \multirow[t]{2}{*}{ Amazon Score } & 0.022 & $0.169 * * *$ & 0.028 & $0.169 * * *$ & 0.026 & $0.170 * * *$ \\
\hline & $(0.089)$ & $(0.057)$ & $(0.095)$ & $(0.057)$ & $(0.093)$ & $(0.058)$ \\
\hline \multirow[t]{2}{*}{ U.S. Topic } & 0.014 & -0.011 & 0.032 & 0.011 & 0.017 & 0.011 \\
\hline & $(0.075)$ & $(0.046)$ & $(0.076)$ & $(0.046)$ & $(0.077)$ & $(0.046)$ \\
\hline \multirow{2}{*}{ U.S. Topic X non-U.S. Media Outlet } & $-0.726 * * *$ & -0.011 & $-0.716^{* * *}$ & -0.004 & $-0.720 * * *$ & -0.030 \\
\hline & $(0.156)$ & $(0.131)$ & $(0.156)$ & $(0.135)$ & $(0.156)$ & $(0.128)$ \\
\hline Genre & $\begin{array}{c}0.197 * * * \\
(0.066)\end{array}$ & & & & & \\
\hline Published in favorable period & & & $\begin{array}{c}0.033 \\
(0.079)\end{array}$ & & & \\
\hline Books published in the same year & & & & \multicolumn{3}{|c|}{$\begin{array}{c}-0.126 * * \\
(0.061)\end{array}$} \\
\hline Media Outlet FE & $\mathrm{x}$ & $\mathrm{x}$ & $\mathrm{x}$ & $\mathrm{x}$ & $\mathrm{x}$ & $\mathrm{x}$ \\
\hline \multirow{2}{*}{ Rho } & \multicolumn{2}{|c|}{0.049} & \multicolumn{2}{|l|}{0.025} & \multicolumn{2}{|l|}{0.107} \\
\hline & \multicolumn{2}{|c|}{$(0.116)$} & \multicolumn{2}{|l|}{$(0.199)$} & \multicolumn{2}{|l|}{$(0.069)$} \\
\hline \multirow{2}{*}{$\begin{array}{l}\text { Wald test }(\text { rho }=0) \text { Prob }>\chi 2 \\
\text { Obs }\end{array}$} & \multicolumn{2}{|c|}{0.671} & \multicolumn{2}{|l|}{0.898} & \multicolumn{2}{|l|}{0.121} \\
\hline & 3758 & 1414 & 3758 & 1414 & 3758 & 1414 \\
\hline
\end{tabular}

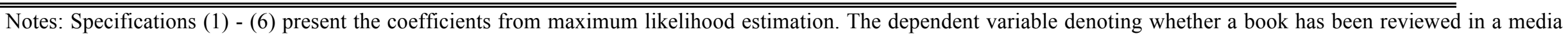

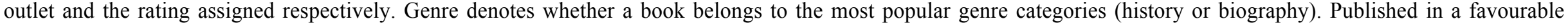

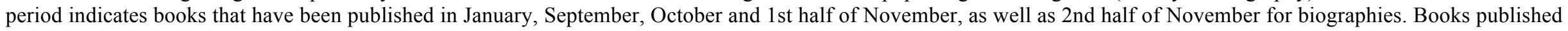

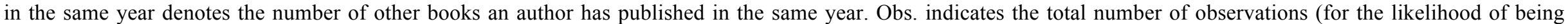

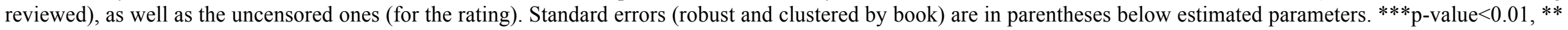
p-value $<0.05, *$ p-value $<0.1$. 


\section{Likelihood of}

being

reviewed

\section{(1)}

Connected Author

First Time Author

Book Prize Winner

\# of Mentions in New York Times

Amazon Score

U.S. Topic

U.S. Topic X non-U.S. Media Outlet

Genre

$0.714 * *$

$(0.153)$

$-0.191 * * *$

(0.066)

$0.139 * *$

(0.067)

$0.021 * * *$

(0.004)

0.022

(0.069)

0.014

(0.056)

$-0.725 * * *$

(0.118)

$0.198 * * *$

(0.048)

Published in favorable period

Books published in the same year

Media Outlet FE

Inverse Mills ratio

$\mathrm{x}$

$\mathrm{x}$

$\mathrm{x} \quad \mathrm{X}$

(2)

$0.243 *$

(0.150)

$-0.120 * *$

(0.063)

$0.150 * * *$

(0.058)

$0.010 * *$

(0.004)

$0.171^{* * *}$

$(0.057)$

$-0.010$

(0.045)

$-0.046$

$(0.168)$

Likelihood of
being reviewed

Rating

Rating

(3)

$0.707 * * *$

(0.153)

$-0.172 * * *$

(0.066)

$0.138^{* *}$

(0.068)

$0.016^{* * *}$

(0.004)

0.028

(0.069)

0.032

(0.057)

$-0.715^{* * *}$

(0.117)

(4)

0.250

$(0.250)$

$-0.122$

(0.081)

$0.153 * *$

(0.073)

0.011

(0.007)

$0.171^{* * *}$

(0.058)

$-0.010$

(0.045)

$-0.057$

(0.301)

0.035

(0.048) being reviewed

(6)

$0.706 * * *$

$0.706^{* * *} \quad 0.457 * *$

(0.153) (0.215)

$-0.200^{* * *} \quad-0.176^{* *}$

(0.066) (0.077)

$0.134 * * \quad 0.198 * * *$

$(0.067) \quad(0.072)$

$0.016^{* * *} \quad 0.016^{* * *}$

(0.004) (0.006)

$0.025 \quad 0.181 * * *$

(0.069) (0.063)

$0.017 \quad-0.005$

(0.056) (0.050)

$-0.716^{* * *} \quad-0.313$

(0.118) (0.248)

$\mathrm{X}$

$-0.124 * *$

(0.054)

\title{
Obs
}

$\begin{array}{r}0.112 \\ (0.299) \\ \hline 3758\end{array}$

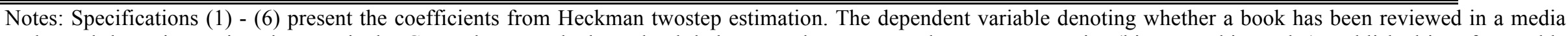

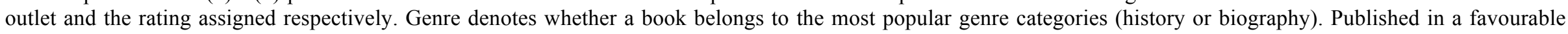

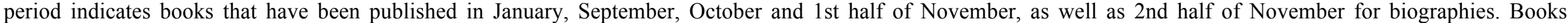

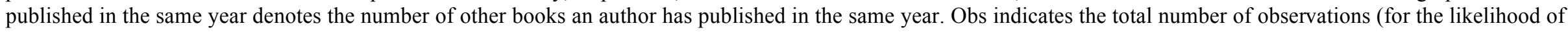

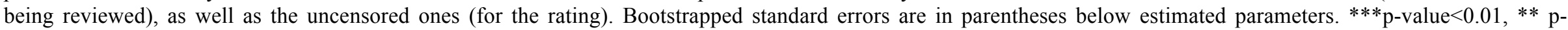
value $<0.05, *$ p-value $<0.1$.
\end{abstract}

